\title{
Evaluation of different manures application on fruit quality of tomato in the derived savannah ecological zone of Nigeria
}

\begin{abstract}
Field experiment was conducted to evaluate the effect of different manures on the fruit quality of tomato in the derived savannah ecological zone of Nigeria. Nutrient components such as Lycopene, vitamin C content, Protein, total mineral content, sugar, lipids ash as well as water content were evaluated as affected by different manure application. Number of days to fruit decay after harvest was also evaluated using standard method. The result from the experiment showed that there were no significant differences among the various manure evaluated on the nutrient components of the test plant as well as the number of days to fruit rottening. However, numerical differences were observed in some cases though not peculiar and or consistent to any of the manure under investigation. Showed that manure type does not significantly affect the fruit quality of tomato.
\end{abstract}

Volume I Issue 2 - 2017

\author{
Abolusoro PF,' Abolusoro SA, ${ }^{2}$ Adebiyi OTV, ${ }^{2}$ \\ Ogunremi JF ${ }^{2}$ \\ 'Department of Agriculture, Kogi state College of Education \\ Technical Kabba, Nigeria \\ ${ }^{2}$ Department of Crop Science, Landmark University, Nigeria
}

Correspondence: Abolusoro PF, Department of Agriculture, Kogi state College of Education Technical Kabba, Nigeria, Tel 080368II527,Email stevabolusoro2005@yahoo.co.uk

Received: July 05, 2017| Published: October 05, 2017

Keywords: fruit quality, tomato, manure, nutrient composition, shelf life

\section{Introduction}

Tomato contributes to a healthy and well balanced diet. They are rich in minerals, vitamins, essential amino acids, sugars and dietary fiber ${ }^{1}$ tomato has an appreciable protein as well as vitamins $\mathrm{A}, \mathrm{C}$ and $\mathrm{D}$ content. ${ }^{2}$ Tomato fruits are consumed fresh in salads or cooked in sauces, soup and meat or fish dishes. They can be processed into purees, juice and ketchup. Canned and dried tomatoes are economically important processed products of tomato. Tomato has become an important cash and industrial crop in various parts of the world. One of the reasons for this increase is that tomato cultivation is now being moved to places and seasons that are originally unsuitable for its productivity thereby resulting in an increase in the production of the crop. ${ }^{3}$ Tomato gives a high yield and it is economically attractive. The average ripe fruit has been reported to contain about $1.0 \mathrm{~g}$ of crude protein, 90 kilocalories of energy, $24 \mathrm{mg}$ of phosphorus, $0.4 \mathrm{~g}$ of iron, $1000 \mathrm{Iu}$ of Vitamin A, 25mg of vitamin C, $0.04 \mathrm{mg}$ of Riboflavin, $0.05 \mathrm{mg}$ of thiamin and $0.1 \mathrm{mg}$ of niacin. ${ }^{1}$ It is also rich in essential amino acid, sugar and dietary fiber. ${ }^{4}$ Tomato is consumed in diverse ways including raw in salads or cooked in sauces, soup, meat or fish dishes. It can be processed into purees, juices, ketchup, and drinks or sliced and sundry. The fruit is rich in Lycopene which may have benefial health effects. ${ }^{5}$ Tomato requires nutrient such as N, P, K, $\mathrm{Mg}, \mathrm{Ca}, \mathrm{Na}$ and $\mathrm{S}$ for good production. These nutrients are specific in function and must be supplied to plant at the right time and in the right quantity. ${ }^{6}$ Large quantities of organic wastes such as poultry manure are available especially in urban centers and are effective sources of nutrient for vegetables such as tomato. ${ }^{7}$ Other organic manures which include compost manure (domestic degradable waste), farmyard manure (animal dungs) which are also available in very large quantities should be considered as a cheap alternative source of fertilizer. Their conversion into manure will help to reduce the pollution danger associated with their disposal and in turn will help to improve the soil nutrient. The need to produce tomato fruits with high nutrient value, healthier and long shelf life is imperative. Hence, the study was conducted to determine the nutrient value and shelf life of tomato fruit based under different manures

\section{Materials and methods}

The experiment was carried out at the Department of Crop Science research farm, University of Nigeria, Nsukka located in the derived savannah ecology (latitude 06`52 N, longitude 07`24 E $447.26 \mathrm{~m}$ above sea level (Mbagwu 1990). The soil is texturally a clay loam soil. The soil was acidic and deficient in organic matter, Nitrogen, Potassium and phosphorus which are the ultimate determinant of soil fertility. Application of organic and inorganic manure to the soil helped to improve its nutrient status, the $\mathrm{pH}$ value of poultry manure and phytofeed and pig manure can help to reduce the acidity of soil than the NPK.

\section{Nutrient analysis on tomato fruits}

All fruits were harvested at maturity, and samples were analyzed for total mineral matter. Analysis was carried out according to the method described by Kacar (1995) and the amounts of lycopene, was determined using the anatomic absorption spectrometer. The fruit samples from each treatment ( 4 per replicate; 12 per treatment) were minced in a blender and the content of soluble sugars, vitamin $\mathrm{C}$ and water in the juice of fruit samples were measured. Fruit protein was calculated from the kjeldahl nitrogen using a conversion factor of 6.25. Lipid was estimated by exhaustively extracting a known sample weight with petroleum ether $\left(\mathrm{BP} 60^{\circ} \mathrm{C}\right)$ using a TecatorSoxhlet apparatus. Fiber content was estimated from the loss in weight of the crucible and its content on ignition.

\section{Determination of tomato shelf life}

To determine shelf life of organically and inorganically produced tomato, ten tomatoes were selected from each treatment and were placed on the table and observed for 10days to determine the level of spoilage. The result was presented in percentage. 


\section{Statistical analysis}

The data collected were subjected to analysis of variance (ANOVA) and treatment means were compared using the Fisher least significant difference (F-LSD) at 5\% probability level as stipulated by (Obi 2002). Statistical analysis was done using Discovery Edition 3.

\section{Results}

Table 1 shows the effects of different manure on the nutrient compositions of tomato. There were significant variations among manure types with respect to nutrient composition of tomato. Poultry manure had the highest Lycopene $(22.52 \mathrm{mg} / \mathrm{g})$, ash (16.59\%), sugar

Table I Effect of different manures on the phyto chemical contents of tomato

\begin{tabular}{|c|c|c|c|c|c|c|c|}
\hline \multirow[t]{2}{*}{ Manure types } & Lycopene & Sugar (\%) & Protein (\%) & Water (\%) & Vitamin C (Mg/kg) & Lipid (\%) & Ash (\%) \\
\hline & \multicolumn{7}{|l|}{$\mathrm{Mg} / 100 \mathrm{~g}$} \\
\hline Phyto feed & 19.93 & 3.54 & 28.59 & 85.56 & 159.74 & 1.33 & 14.77 \\
\hline Pig & 21.62 & 3.55 & 27.69 & 83.58 & 139.96 & 1.26 & 15.19 \\
\hline Poultry & 22.53 & 3.96 & 27.69 & 83.21 & 127.78 & 0.92 & 16.59 \\
\hline NPK & 19.29 & 3.47 & 28.15 & 83.51 & 105.65 & 1.01 & 16.16 \\
\hline Mean & 20.85 & 3.63 & 28.03 & 83.97 & 133.28 & 1.13 & 15.68 \\
\hline F- LSD $(0.05)$ & 0.32 & 0.14 & 0.45 & 0.05 & 0.05 & 0.03 & 0.09 \\
\hline
\end{tabular}

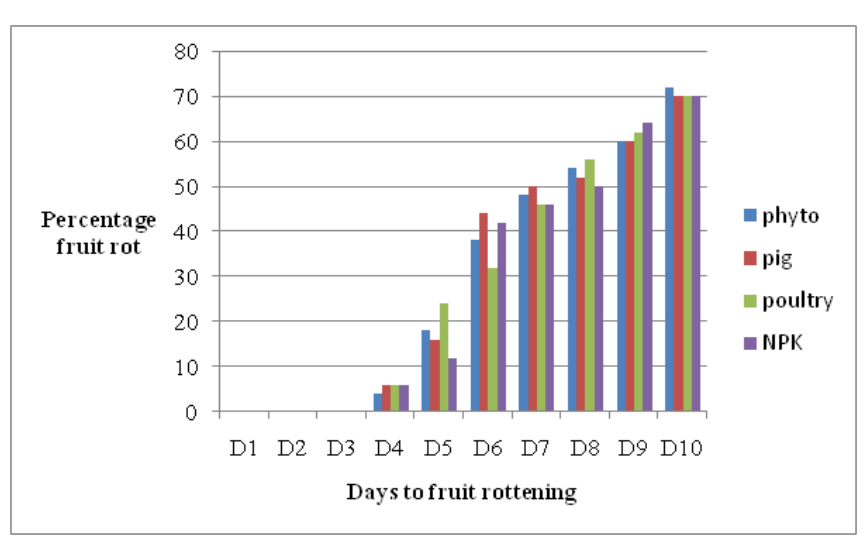

Figure I Effects of Manure types on tomato storability (Cumulative) in percentage.

\section{Discussion}

\section{Effects of different manures on fruit quality}

Organic and inorganic manure treatments at higher rates recorded more Lycopene than at lower rates including control. This could be ascribed to mineralization and effective utilization of plant nutrients. The result is in conformity with different findings on carotene and Lycopene contents in organic tomatoes such as ${ }^{8,9}$ when compared with inorganic methods Furthermore, Julroszek et al. ${ }^{10}$ reported differences between organic and inorganic tomatoes as a result of the fertilizer used in both cases. Organic farming doesn't use nitrogenous fertilizers; as a result, plants respond by activating their own defense mechanisms, increasing the levels of all antioxidants. Vallverdu Queralt et al. ${ }^{11}$ pointed out that, the more stress plants suffer, the more polyphenols they produce. Oliveira et al. ${ }^{12}$ also reported that, tomato fruits from organic farming experienced stressing conditions that resulted in oxidative stress and the accumulation of higher
$(3.46 \%)$ and the lowest water $(83.21 \%)$ and lipid (0.92). Phytofeed manure had the highest protein (28.59), vitamin $\mathrm{C}$ and highest water (85.21\%). Lycopene (19.23), sugar (3.47\%) and vitamin C (105.65 $\mathrm{mg} / \mathrm{kg}$ ) were lowest in NPK. The cumulative effect of different manure on shelf life of tomato fruit are presented in Figure 1. There were no exhibitions of significant differences among manure types with respect shelf life of tomato. However, at day 10 of the observation, $72 \%$ of fruit rot was observed in phytofeed, while poultry, pig and NPK fertilizer had $70 \%$ rot. This observation however can be varied by the variety of tomato utilized for the experiment as well as the season when it was conducted.

concentrations of soluble solids such as sugars and other compounds contributing to fruit nutritional quality such as vitamin $\mathrm{C}$ and phenolic compounds. Additionally, Lumpkin $\mathrm{HM}^{13}$ had also reported an increase in Lycopene content of organically grown tomato compared with the inorganic.

Adeniyi et al. ${ }^{14}$ observed that Lycopene content was highest at $20 t /$ ha poultry manure and that organic source had higher Lycopene content than the inorganic. Tomato fruit is a rich source of ascorbic acid (vitamin C).The organic manure treatment recorded higher amount of ascorbic acids compared with the inorganic manure. The highest ascorbic acid content $(185.73 \mathrm{mg} / 100 \mathrm{~g})$ was recorded in crop that received (phyto feed, $20 \mathrm{~kg} / \mathrm{ha}$ ) and was found to be higher than other manures and the control. Caris Veyrat, ${ }^{15}$ Toor et al..$^{16}$ observed that Ascorbic acid content in organically fertilized tomatoes ranges between $29 \%$ and $31 \%$, which is higher than the results obtained from tomatoes that were fertilized with mineral solutions. Similarly, Premuzic et al. ${ }^{17}$ reported that ascorbic acid content in tomatoes cultivated with an organic substrate was higher than hydroponically cultivated tomatoes. Many citations from literature confirm that tomatoes coming from organic cultivation procedures present higher vitamin $\mathrm{C}$ content than fruits from inorganic cultivation. ${ }^{18}$

This is because organic farming doesn't use nitrogenous fertilizers, as a result, plants respond by activating their own defence mechanisms, increasing the levels of all antioxidants. Vallverdu Queralt et al. ${ }^{11}$ pointed out that the more stressed plants suffer, the more polyphenols they produce. Oliveira et al. ${ }^{12}$ also reported that tomato fruits from organic farming experience stressing conditions that resulted in oxidative stress and the accumulation of higher concentration of soluble solids such as sugars and other compounds contributing to fruit nutritional quality such as Vitamin C and polyphenol compounds. Regarding shelf life of tomato, a non-significant difference in the days to fruit rotting under storage could as well be ascribed to the no variation in the chemical composition of the different treatments. This 
result is however in disagreement with Ghorbani et al. (2008), who observed that application of inorganic fertilizers improved tomato storability while the effect of compost extract were inconsistent and non significant. This observation however can be varied by the variety of tomato utilized for the experiment as well as the season when it was conducted.

\section{Conclusion}

The nutrients composition of tomato fruit is affected by the levels of manure application either organic or inorganic manure, However organic manure increases some of the nutrients component better than the inorganic but not significantly different in most cases based on our findings in the present investigation. The shelf life too is not affected by the manure type as there were no significant differences in most cases among the various treatments investigated.

\section{Acknowledgements}

I thankful to Ogunremi JF for carrying out the laboratory analysis.

\section{Conflict of interest}

The author declares no conflict of interest.

\section{References}

1. Sigmund R, Gustav E. The cultivated plants of the tropics and subtropics. Food and Agriculture organization of the United Nations. 1991. 133-140.

2. Van Eck J, Kirk D, Walmsley AM. Methods in Molecular Biology. 2006;343:459-473.

3. Bodunde JG, Erinle ID, Eruotor PG, et al. Recommendation for the release of four heat tolerant Tomato varieties. Professional and Academic Board, Nigeria; 1993. p. 1-165.

4. Kallo D. Effect of irrigation intervals and N.P.K application. Nigeria journal of Agriculture, food and environment. 1991;8(10):59-62.

5. Mouvaki E, Gizzi S, Rossi R, et al. Passionflower Fruit-New Source of Lycopene. J Med food. 2005;8(1):104-106.

6. Shukla V, Naik LB. Agro-Technique for Solanaceous Vegetable, in horticulture. Malhorta publishing house, India; 1993. p. 364-399.
7. Adediran JA, Taiwo LB, Sobulo RA. Comparative nutrient values of some solid organic wastes and their effect on tomato (Lycopersiconesculentum) yield. African Soils. 2003;33:99-113.

8. Veazie P, Roberts, W, Collins J. Lycopene Content among organically produced tomatoes. Journal of Vegetable Science. 2007;12(4):93-106.

9. Ross F, Godani F, Bertuzzi T, et al. Health-promoting substances and heavy metal content in tomatoes grown with different farming techniques. Eur J Nutr. 2008;47(5):266-272.

10. Julroszek P, Lumpkin HM, Yan R, et al. Fruit quality and bioactive compounds with antioxidant activity of tomatoes grown onfarm:comparison of organic and conventional management systems. $J$ Agric Food Chem. 2009;57(4):1188-1194.

11. Vallverdú Queralt A, Jáuregui O, Medina Remó A, et al. Evaluation of a method to characterize the phenolic profile of organic and conventional tomatoes. J Agric Food Chem. 2012;60(13):3373-3380.

12. Oliveira AB, Moura CFH, Gomes Filho E, et al. The Impact of Organic Farming on Quality of Tomatoes is Associated to Increased Oxidative Stress during Fruit Development. Plos One. 2013;8(2):e1-e56354.

13. Lumpkin HM. A comparison of lycopene and other phyto chemicals in tomatoes grown under conventional and organic management system. Tech Bull. 2005;34:4-48.

14. Adeniyi H, Ademoyegun O. Effects of different Rates and sources of fertilizer on yield and Antioxidant component of tomato (Lycopersiconlycopersicum). Agricultural journal. 2012;7(2):135-138.

15. Caris Veyrat C, Amiot MJ, Tyssandier V, et al. Influence of organic versus conventional agricultural practice on the antioxidant micro constituent content of tomatoes and derived purees; consequences on antioxidant plasma status in humans. J Agric Food Chem. 2004;52(21):6503-6509.

16. Toor RK, Savage GP, Heeb A. Influence of different types of fertilizers on the major antioxidant components of tomatoes. Journal of Food Composition and Analysis. 2006;19(1):20-27.

17. Premuzic Z, Bargiela M, Garcia A, et al. Calcium, iron, potassium, phosphorus, and vitamin $\mathrm{C}$ content of organic and hydroponic tomatoes. Hort Science. 1998;33(2):255-257.

18. Lundegardh B, Martensson A. Organically produced plant foodsevidence of health benefits. Acta Agriculture Scandanavica J Soil \& Plant Science. 2003;53(1):3-15. 